\title{
SMEs Awareness of Global Performance Issues; Case of Lebanon and Romania
}

\author{
Riad Makdissi, Danie Khawaja, Selim Mekdessi ${ }^{1}$
}

\begin{abstract}
This article focuses on the awareness level of the Lebanese and Romanian SMEs to global performance concepts and subsequently social responsibility. It especially emphasizes the possible link between social performance and financial performance within the companies and thus advances the financial policy of SMEs, their socially responsible practices and reasons for this commitment to the search for a global performance. To this end, a quantitative method has been established based on data generated from a questionnaire sent to Lebanese and Romanian SMEs. This research has an exploratory aim. The observed sample of SMEs shows the theory or hypothesis in which the SMEs are inscribed. A larger number of SMEs would have improved the external validity of the results.
\end{abstract}

Keywords:Global Performance, Financial Performance, Social Performance, Lebanese SMEs, Romanian SMEs, Corporate Social Responsibility

\section{Introduction}

Talking about performance is looking into everything that helps improve the value for money and achieve strategic goals (Lorino, 2003). According to Bourguignon (1997), the achievement of these objectives can be understood in the strict sense (result, outcome), or in the broad sense of a process that leads to the result (action). "These goals can be financial, economic, social, environmental... Chardonnet and Thibaudon (2014) have defined the three pillars of performance - goals, means and results - by the triangle of performance based on relevance (appropriateness means / goals), effectiveness (degree of achievement of goals) and efficiency (effectiveness related to means). Making economic and social goals compatible will aim at ensuring a sustainable global performance by calculating the costs as well as visible and hidden performance (Savall and Zardet, 2009). Sustainable global performance is therefore defined in the socio-economic theory of organizations by two components: social performance and economic performance (Savall and Zardet, 2005). The design of the performance is strongly influenced by the convictions of the owner-manager (Bergeron and al., 2014).

According to Baayoud (2005), there can be no sustainable economic performance without social performance. The social and societal performance of enterprises expand the concept of performance to encompass the corporate social responsibility (CSR) (Germain and Trébucq, 2004), which is defined by the European Commission (2001) as "the voluntary integration by enterprises of social and environmental concerns in their business operations and their relations with their stakeholders." The first model of societal performance was suggested by Carroll (1979). It covers three dimensions of societal performance: a basic definition of social responsibility: it is to take into account both the economic viability and legal obligations, but also to have an ethical behavior in line with the social standards and expectations and a discretionary responsibility , a listing of the issues that justify the existence of a social responsibility. Among the social areas in which we have a responsibility, we can mention the environment, discrimination, and product safety, as well as a specification of the philosophy of action, reaction, and response (Reaction or proaction to these questions?).

In this research we try to see to what extent Lebanese and Romanian SMEs take into account social dimensions in the assessment of their performance in parallel with economic and financial dimensions. Do SMEs in Lebanon and Romania go beyond the strictly financial view of performance toward an increasingly comprehensive and sustainable performance approach?

The main hypothesis is that SMEs in Lebanon and Romania are in an embryonic state on CSR and the improvement of global performance and awareness of social performance issues are mainly undertaken in order to improve financial performance and create value.

To provide answers to these questions, a study was conducted among 50 Lebanese SMEs and 22 Romanian SMEs. We start our work with a literature on global performance and the link between financial performance (FP) and social performance (SP) of enterprises from a theoretical viewpoint in order to identify later on the research field and the adopted methodology and to present the results obtained afterwards followed by a discussion.

\section{From an economic and financial performance to a global performance}

Speaking of financial performance is mainly speaking of profitability, assessment of liquidity, estimated future profit, competitiveness analysis and corporate bankruptcy forecast (Zeller and al. 1996). With financial scandals and bankruptcies that hit the world in recent years, particularly following the financial crisis of 2007-2008, the concept of financial performance was reviewed to try to define it in a more responsible and sustainable way (Grandin and Saidane, 2011). It will rather be a global enterprise performance. According to Marcel Lepetit, it is like "a multidimensional, economic, social and societal, financial and environmental target (or goal), concerning enterprises and human societies, employees and citizens" (Dohou and Berland, 2007). According to Maurel and Tensaout (2014), it is indirectly determined "by business practices, social practices and societal-environmental practices." Thus, it is the fact of articulating the financial and ESG (environmental, social and governance) stakes (Luthi and Mailly, 2015). In fact, according to Capron and QuairelLanoizelée (2006), "the concern for global performance and its valuation appears from the moment the company is not only bound to financial reporting by its owners, but must also account for its behavior in societal and environmental matters to a multitude of stakeholders." This allows focusing on the stakeholder theory (Freeman, 1984). According to Capron and Quairel-Lanoizelée (2010), this theory questions the compatibility between the economic rationality of the company and its societal concerns. Referring to Cazal (2011), the

\footnotetext{
${ }^{1}$ Riad Makdessi, Ph.D., Associate Professor, Faculty of Economic Sciences and Business Administration, Lebanese University, Lebanon. Danie Khawaja, Ph.D. candidate, CNAM Paris, France

Selim Mekdessi, Ph.D., Full Professor, Faculty of Economic Sciences and Business Administration, Lebanese University, Lebanon.

Correspondence concerning this article should be addressed to Riad Makdessi, Lebanese University, Faculty of Economic Sciences and Business Administration, Branch III, Tripoli, North Lebanon. E-mail: riad_mcdessy@ hotmail.com
}

DOI: 10.9790/487X-1810014956 www.iosrjournals.org $\quad$ wage


main finding of the stakeholder theory is that it is necessary to include the interests and rights of non-shareholders in the governance of the company. Some researchers, such as Freeman and McVea (2001), speak of the existence of a positive impact of commitment in CSR on financial performance. Responding to the expectations of stakeholders enhances the company's reputation, which will have a positive impact on financial performance. According to Jensen (2002) increasing social performance leads to an increase in the firm's market value on the long term (Hirigoyen and Poulain- Rehm, 2014). Thus, in this article, we will be further detailing the relationship and interaction between financial performance and social performance of companies based on several theories and hypotheses developed by several researchers.

\section{Link between Financial Performance and Social Performance of companies: theoretical perspectives}

The relationship between FP and SP has been empirically studied for over 30 years in order to validate these concepts to those who believe that CSR practices are costly and will adversely affect the profitability of the company (Gond, 2006). A study of Orlitzky and al. (2003), followed by a meta-analysis, has demonstrated that the relationship between FP and SP tends to be bidirectional and reputation seems to be an important mediator in this relationship. Similarly, according to these authors, the universally positive relationship varies (from very positive to slightly positive) due to contingencies such as reputation effects, measures of financial performance or communication of social performance of companies.

Rousseau (2012) has highlighted the various theories focusing on the causality between social performance and financial performance.

- Good management theory (hypothesis of the social impact): firms that have a high societal performance (low) are well (mis) managed companies, resulting in high financial performance (low). It refers to the stakeholder theory (Freeman, 1984).

- Slack Resource theory (hypothesis of available funds): companies with high financial performance have free resources they can allocate to activities falling within the scope of CSR and likely to improve their societal performance.

Moreover, Allouche and Laroche (2005) identify two additional theories which they label assumption of arbitration (Friedman, 1962, 1970; Vance, 1975) and assumption of opportunism (Preston, O'Bannon, 1997) to elucidate a negative link between the two performance categories. In the managerial opportunism assumption, there tends to be a prioritization of the leaders' interests at the expense of shareholders and stakeholders. For instance:

- If the financial performance improves, there will be a reduction of social expenditure in order to maximize leaders' gains;

- If the financial performance decreases, there will be a commitment to social programs aiming at hiding the losses incurred.

The Management authors engaged in a frantic multiple studies try to prove that there is a positive link between social performance and financial performance without the demonstration can be made conclusively (Orlitzky \& al., 2003; Allouche, Laroche, 2005; Mekdessi 2007).

However, the assumption of arbitration is based on the neoclassical theory of the firm which believes that CSR has a negative impact on financial performance because this commitment will generate additional costs, which will consequently decrease profits and competitiveness of the company (Bnouni, 2011).

These sometimes conflicting theories will enable us to tell later on in which hypothesis we can include the model or the reas on behind which Lebanese SMEs engage in CSR and are interested in global performance issues.

SMEs: quantitative and qualitative characteristics

According to the National Institute of Statistics and Economic Studies (INSEE), "The category of micro, small and medium enterprises (SMEs) is made up of enterprises which employ less than 250 persons and whose annual turnover does not exceed EUR 50 million or whose total annual balance sheet does not exceed $€ 43$ million." This definition points to a quantitative approach.

The table below summarizes the characteristics of SMEs in terms of number of employees, turnover and total balance sheet.

\begin{tabular}{|l|l|l|l|l|}
\hline Business category & Employees & Turnover & or & Total balance sheet \\
\hline Medium & $<250$ & $\leq 50$ million euros & $\leq 43$ million euros \\
\hline Small & $<50$ & $\leq 10$ million euros & $\leq 10$ million euros \\
\hline Microenterprise & $<10$ & $\leq 2$ million euros & $\leq 2$ million euros \\
\hline
\end{tabular}

Table 1. SMEs characteristics

Source: European Commission (2003)

In terms of qualitative or rather organizational characteristics of these companies, some researchers (Julien, 1990; Mintzberg, 1990; Mahé de Boislandelle 1996; Marchesnay, 2003; Torres, 2003; Courrent, 2012) have defined the SMEs management specificities according to the following criteria:

- $\quad$ Small size and simple structure

- Management centralized around the owner-manager

- Low specialization of tasks

- Intuitive or little formal strategy

- Simple internal and external information systems

- Structural shortage in resources

- $\quad$ Sense of urgency

- Proximity management: hierarchical, functional, spatial, temporal proximity... According to Torres, proximity is the central element that allows to define a wide variety of SMEs types on one hand, and to explain the specific behavior of SME managers on the other hand.

SMEs related management characteristics support various proximities which characterize these enterprises.In this article, we are focusing on Lebanese and Romanian SMEs and their main characteristics.

\section{Research Field and Methodology}

SMEs represent the immense majority of enterprises in Lebanon and in Romania. Their changing practices towards a greater accountability and the expansion of the performance framework towards a global performance hence constitute a major issue.

In fact, Lebanese SMEs represent $97 \%$ of all enterprises in Lebanon. 50\% of the Lebanese workforce is employed in SMEs (CCI, 2014). According to the VAT register, only 16,000 companies, out of nearly 175,000 , report having a turnover of over $\$ 100,000$ (Sbeih, 2009). It is worth noting that over $74 \%$ of Lebanese SMEs were founded by their current owners. Other SMEs are family businesses (Badreddine, 2011).

Similarly, Romanian SMEs play a central role in the economic development of their country. They represent $99.7 \%$ of Romanian companies and $66 \%$ of employees work in SMEs. The development potential of this sector is enormous yet, since the number of SMEs in Romania is two times lower than the EU average (SDC, 2015). 
As for the distribution of SMEs by Lebanese regions, most SMEs are located in Mount Lebanon, accounting for $36.46 \%$ of the total of these companies in Lebanon. However, in the Bekaa region, there are only $13.07 \%$ of Lebanese SMEs. With regard to the sectorial breakdown, most Lebanese SMEs operate in the field of trade; in fact, they represent $62.59 \%$ of total SMEs in Lebanon. The industrial sector comes second with $10.47 \%$, followed by the services sector with $8.35 \%$. As for SMEs working in the construction and real estate sector, they only represent $1.46 \%$ (Badreddine, 2011).

On the other hand, the number of SMEs in Romania differs from one region to another due to some differences in the level of development, and the corporate spirit and culture (Platon \& Antonescu, 2009). The largest number of SMEs is located in Bucharest (68.471 SMEs) and the smallest in the Southwest (26.163 SMEs). The distribution by the Chamber of Commerce and Industry in Romania (CCIR) was as follows: $31.5 \%$ of Romanian SMEs are based in Bucharest, $12.5 \%$ in the Northwest, $12.3 \%$ in the center, $10.1 \%$ in the Southeast, 9.8\% in the South, 9.4\% in the West, $9.3 \%$ in the Northeast and 5.1\% in the Southwest. As for the sectorial breakdown, the economy of Romania focuses mainly on services, which represent $51.7 \%$ of the GDP and employ $39 \%$ of the national workforce, with the industrial sector having accounted for $38.3 \%$ of the GDP in 2013 and having employed a third of the working population (33\%) while agriculture accounts for nearly $10 \%$ of the GDP in Romania and employs $28 \%$ of the country's workforce.

These elements were taken into account in the construction of our sample of companies; the sample of Lebanese SMEs encompasses 50 companies while we have established 71 contacts with SMEs in Romania and the rate of response and interview acceptance was $31 \%$. The graphs below show the sectorial distribution of the samples studied.

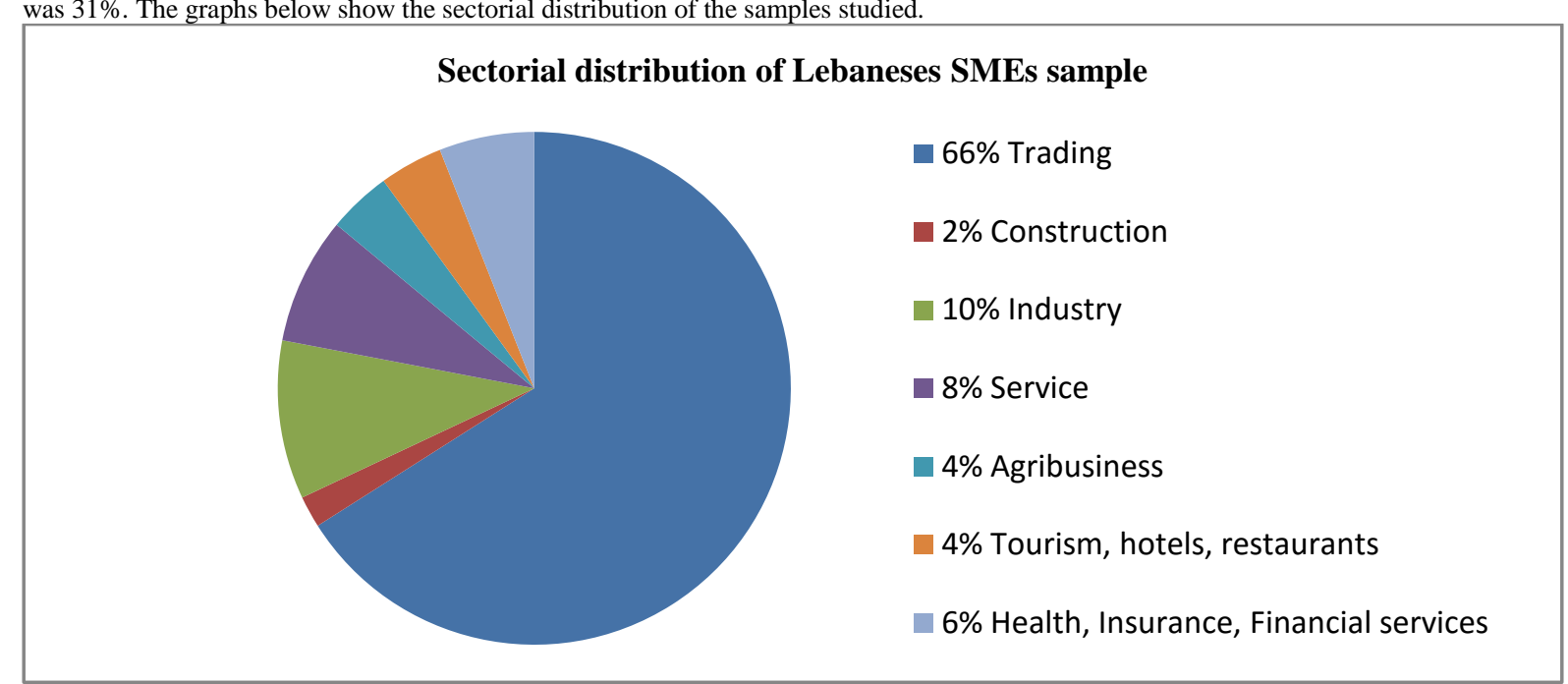

Graphic 1: Sectorial distribution of Lebanese SMEs sample

\begin{tabular}{|l|l|}
\hline Sectorial distribution of Romanian SMEs sample & $18.2 \%$ Services \\
& $\square .1 \%$ Web services \\
& $\square .1 \%$ Auto \\
& $\square .1 \%$ Computer \\
& $\square 18.2 \%$ Health \\
& $\square .1 \%$ Construction \\
& $18.2 \%$ Trading \\
& \\
& $9.1 \%$ Agrobusiness \\
\hline
\end{tabular}

Graphic 2: Sectorial distribution of Romanian SMEs sample

This research used a quantitative method, based on data issued from a questionnaire sent to Lebanese and Romanian SMEs. This study focuses on a sample of 50 Lebanese SMEs and 22 Romanian SMEs. It is important to note that the representation is only partially verifiable in general. For data analysis, we used the SPSS software especially for simple analysis as descriptive statistics. Given the limited number of respondents to the questionnaire, this study has an exploratory mission. Therefore, our sample consists of companies with 5 to 196 employees.

\section{Results:}

We mainly focused on the financial policy of SMEs and on elements regarding social performance and their commitment to CSR.

SMEs financial policy: In the following, we will focus on the preferred method of financing among SMEs in Lebanon and Romania, the main financing players and priority goals of their financial policy. 


\section{Means of financing and key players}

Whenever a development opportunity arises, most Lebanese and Romanian leaders head towards the same means of financing: self-financing ( $88 \%$ for Lebanese leaders and $82 \%$ for Romanian leaders) and / or the long and medium term bank credit (66\% of Lebanese leaders and $45.5 \%$ for Romanian leaders, a number of Romanian SMEs are struggling to obtain credit from commercial banks), while $45.5 \%$ of Romanian leaders resort to financing from existing partners.

Targeted interventions of banks can stimulate entrepreneurship and job creation, through special programs designed for SMEs which constitute a key player in the National economy (Chidiac El Hajj, 2015). In this context, most leaders have recourse to their banking partners ( $44 \%$ for Lebanese and $36.4 \%$ for Romanians), to subsidized loans granted by commercial banks ( $28 \%$ for the Lebanese, especially the loans guaranteed by Kafalat, and $36.4 \%$ for Romanians), and to their accountant or accounting and finance consulting firm (12\% for Lebanese and $9 \%$ for Romanians).

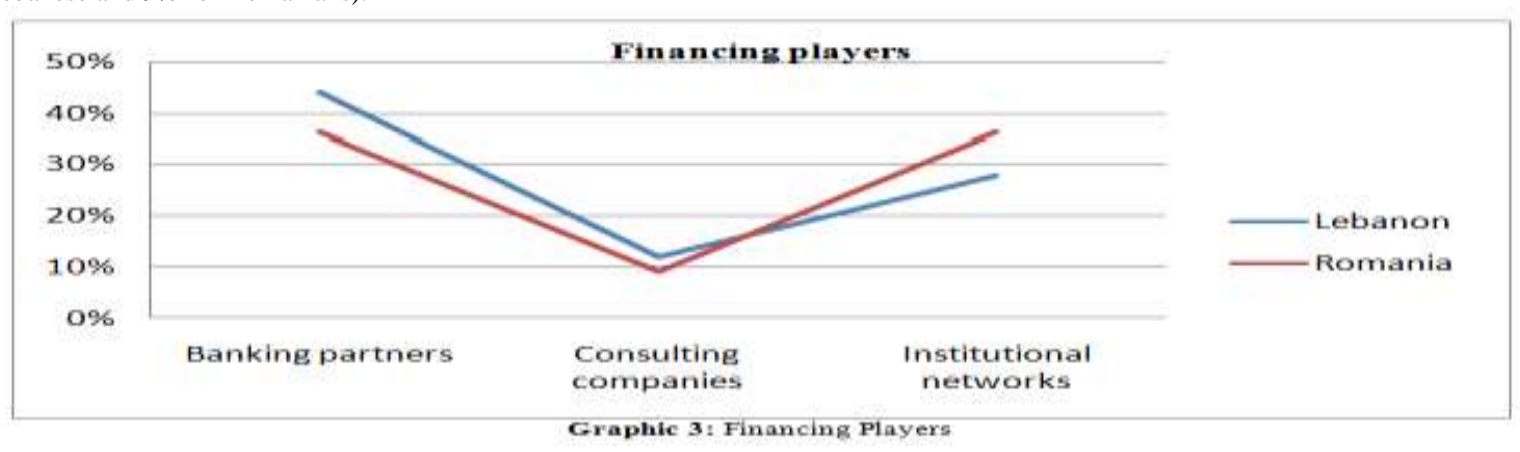

In terms of preferences relevant to the means of financing for the company's development, we noticed that the Lebanese and Romanian leaders prefer to rely primarily on self-financing and on financial debt in second place.

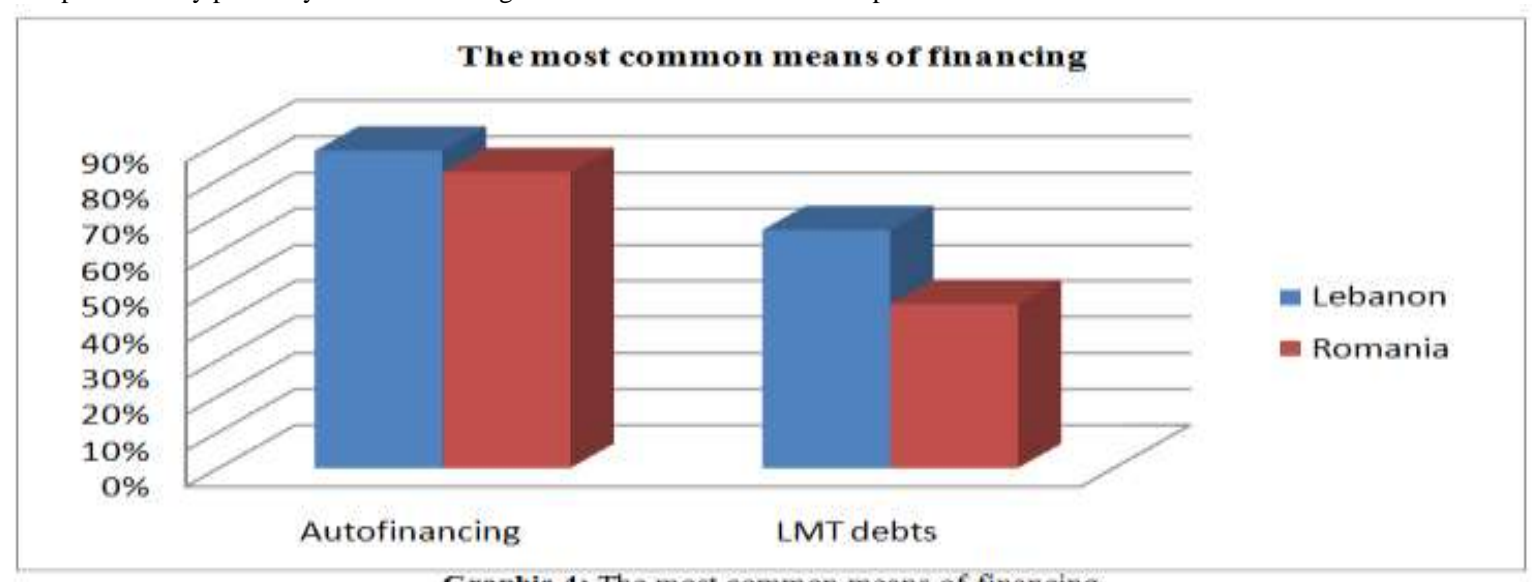

Moreover, SMEs are facing various difficulties in financing their activities. These difficulties can be summarized in particular in terms of insufficient self-financing (28\%), cash flow difficulties (26\%), refusal of medium and long term bank loans (16\%) and excessive delays in obtaining financing $(14 \%)$.

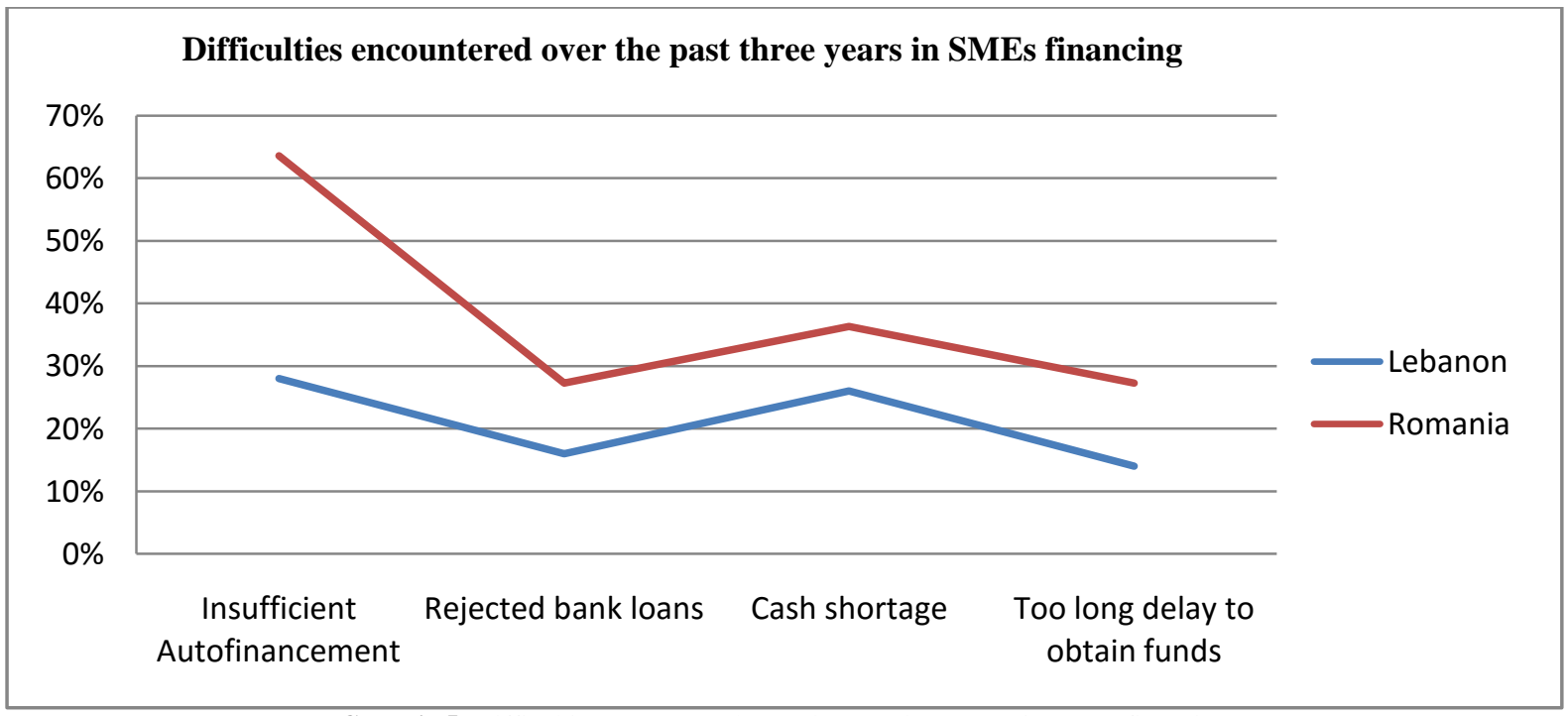

Graphic 5: Difficulties encountered over the past three years in SMEs financing 
The difficulties in the financing of Romanian SMEs outstrip those of Lebanese SMEs and they are much more at the level of inability of self-financing.

Priority goals:

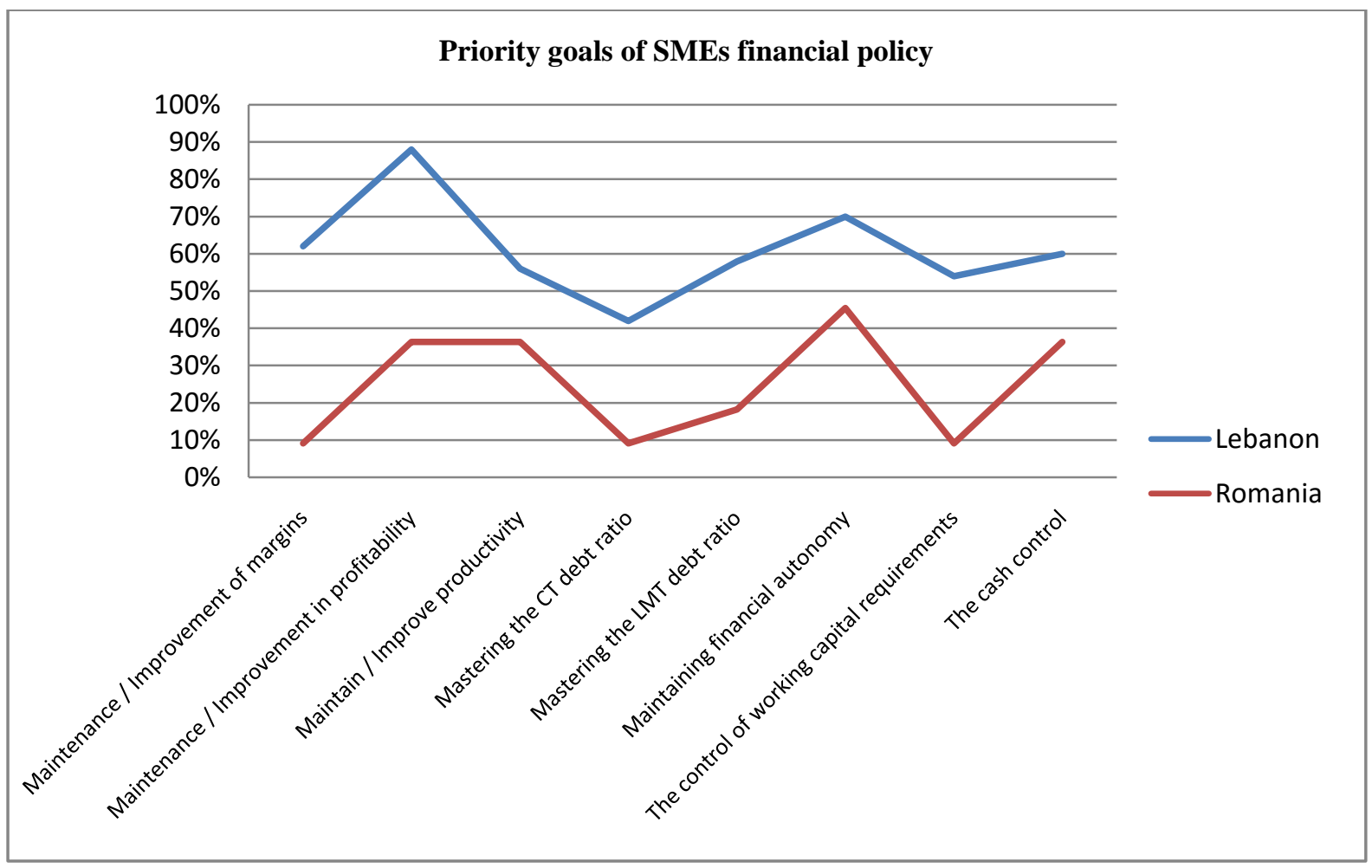

Graphic 6: Priority goals of SMEs financial policy

A discrepancy between the Lebanese and the Romanian cases is noted; the majority of the Lebanese leaders (more than $50 \%$ of the leaders) totally agree to the listed primary objectives while less than $50 \%$ of the Romanian leaders are not interested in taking those objectives into consideration in their financial policies.

$88 \%$ of the Lebanese leaders see that primary objectives of their financial policy consist of maintaining or improving profitability, while only $36 \%$ of the Romanian leaders have the same point of view. $70 \%$ and $45 \%$ agree on maintaining a financial autonomy, respectively Lebanon and Romania, $62 \%$ and $9 \%$ agree on maintaining or improving the margins (note that the majority of the Romanian leaders are neutral $45 \%$ ), $56 \%$ and $36 \%$ on maintaining or improving the productivity, $58 \%$ and $18 \%$ on controlling the long-term debt ratio (36\% of the Romanian leaders are neutral), $60 \%$ and $36 \%$ on controlling cash; $54 \%$ and $9 \%$ on controlling the working capital (36\% of the Romanian leaders are neutral); $42 \%$ and $9 \%$ on controlling the short-term debt ratio ( $36 \%$ of the Romanian leaders are neutral).

According to this section on financial policy, we can note that Lebanese and Romanian SMEs expressed a preference for the selffinancing and bank loans regarding funding sources. As a result, bank partners are their key players regarding the research of funding. Moreover, the main objective of Lebanese SMEs financial policy is to maintain or improve their economic or financial profitability while Romanian SMEs main objective is to maintain a financial autonomy (equity /total assets) for a better economic and financial performance.

Therefore, SMEs rely heavily on banking institutions as they are their main funding sources. In order to motivate and encourage the SMEs to engage in socially responsible practices and to adopt an approach to promote the overall strategy, banks may require the compliance to socially responsible criteria in return for loan granting. SMEs will thus be obliged to respect these criteria to ensure their survival and development.

\section{CSR and social performance}

Studying to what extent the SMEs are engaged in a global performance approach implies perusing the financial policies of the SMEs in addition to their social practices. It is also interesting to highlight the main reasons behind the implementation of CSR practices in SMEs. The primary ground for the implementation of CSR practices is the will of the leaders to improve their company's performance. Moreover, among the partners that might induce the Lebanese and Romanian SMEs to implement sustainable development actions and CSR, we can find customers, suppliers, shareholders and the community.

\section{Policies towards employee:}




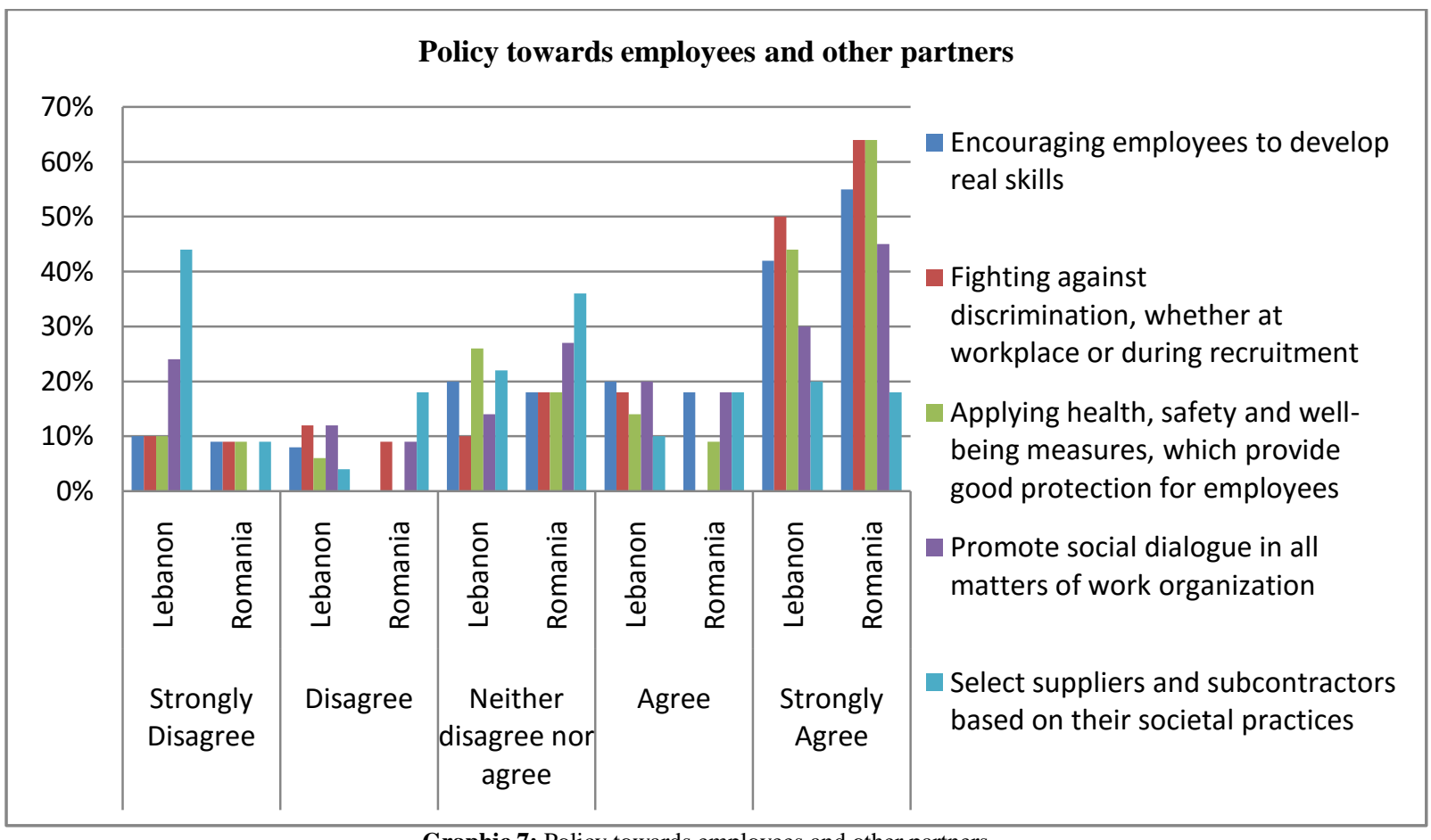

Graphic 7: Policy towards employees and other partners

Concerning the SMEs policy towards employees, $50 \%$ of the Lebanese SMEs and $64 \%$ of the Romanian SMEs claim that they fought against discrimination, whether at the workplace or during recruitment; $44 \%$ and $64 \%$ respectively say that they have applied health, safety and well-being measures, providing the employees with a fair protection, $42 \%$ and $55 \%$ declare that they have encouraged their employees to develop real skills; $30 \%$ and $45 \%$ state that they have promoted social dialogue on all issues regarding the organization; while $44 \%$ of the Lebanese SMEs don't select their suppliers based on their societal practices and 36\% of the Romanian SMEs have no preference concerning the suppliers selection.

Therefore, the main social practices for both countries focus on fighting against discrimination, the application of health, safety, and well-being measures and encouraging employees to develop real skills.

\section{Social performance:}

Measuring social performance isn't easy as it relies on qualitative elements which may be intangible. In order to measure the performance, it is necessary to use some indicators or factors related to social phenomena such as absenteeism and work-related accidents or recruitment and employees motivation.

\section{- Extent of social phenomena within the SMEs}

The greater the intensity of these phenomena, the higher social performance is negatively affected. $24 \%$ of the Lebanese SMEs and $36 \%$ of the Romanian SMEs believe that their absenteeism rate is high, $32 \%$ and $27 \%$ respectively see that work-related accidents are also high; $12 \%$ and $36 \%$ believe in a high turnover, $18 \%$ and $27 \%$ consider that the social relationships are poor; and finally $18 \%$ and $27 \%$ believe in dissatisfaction with work conditions. The Lebanese SMEs are affected the most by work-related accidents followed by absenteeism, while the Romanian SMEs are affected simultaneously by a high rate of absenteeism and employees turnover.

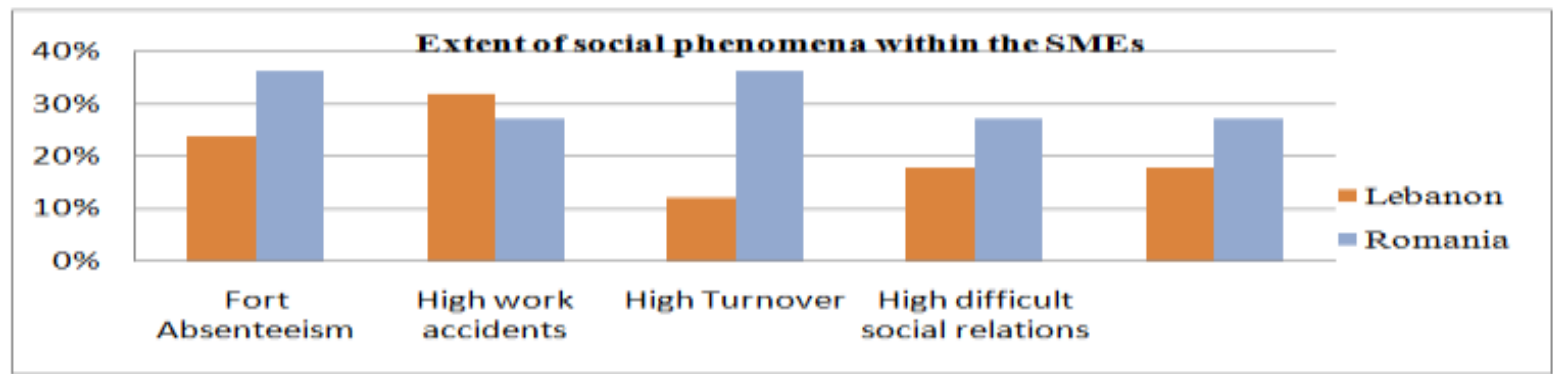

Graphic 8:Extent of social phenomena within the SMEs

To reduce the extent of these phenomena, thus improve the social performance of the companies, it may be interesting to enhance the players' ability to develop their potential. Referring to the socio-economic theory, it may be advantageous to have recourse to a periodically negotiated activity contract (PNAC), a tool created by Savall Henri in 1977. This tool is a simple and operational method aiming at reducing social dysfunctions and subsequently enabling the management of different problems and at the same time the achievement of different social and economic company's objectives. Its purpose is to stimulate the productivity improvement by the means of direct dialogue between two successive hierarchical levels. PNAC rules of game are quite different as they are adapted to each period according to the environment change, the overall results of the company, the results of each unit and the results of the players training. Therefore, the PNAC aims at stimulating productive behaviors of the organization members (Savall and Zardet, 2010). 
- SMEs competence regarding some social phenomena

According to Baayoud (2005), the quality of recruitment is of a major concern. Employment policy aims at creating a state of mind and building a behavior pattern in compliance with the global culture of the company and pertinent to the progress of its performance standards. In this case, we should study if SMEs are competent and well-equipped to deal with phenomena leading to the improvement of social performance in terms of recruitment, training, motivation of employees, social dysfunctions..

According to Schiopoiu Burlea (2015), Romania is highly qualified to develop entrepreneurial skills and training individuals in this area would lead to the progress of entrepreneurial attitudes.

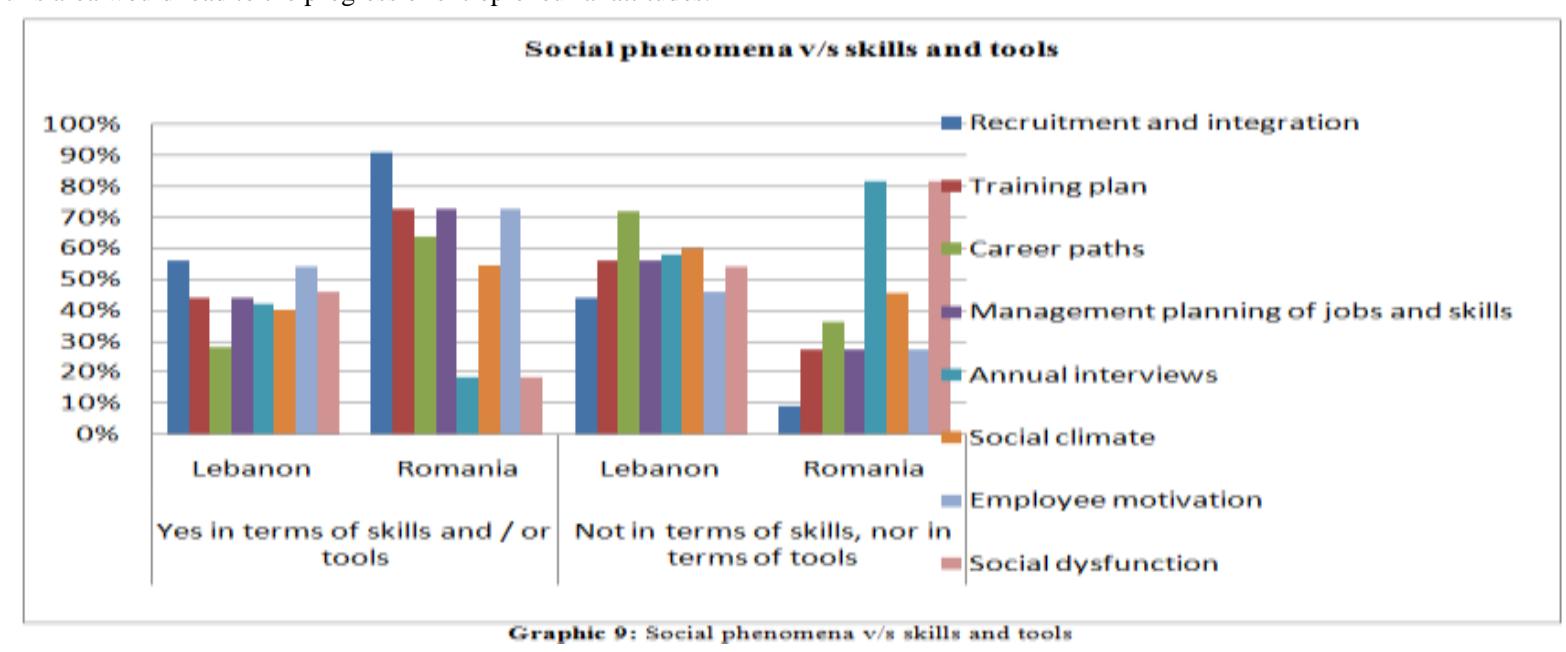

$56 \%$ of the Lebanese SMEs are competent or have the necessary tool to deal with recruitment and integration, and $54 \%$ to deal with the motivation of employees. As for the Romanian SMEs, the majority is competent or has the necessary tool to deal, $91 \%$ with recruitment and integration, $73 \%$ with training planning, forward planning of jobs and skills, and motivation of employees, $64 \%$ with careers paths and $55 \%$ with social environment.

Indeed, being able to manage tools and skills, recruitment, training, social environment, the motivation of employees, social dysfunctions.... etc. will lead to the improvement of the social performance of the company, thus to increasingly engage in a global performance approach.

\section{Discussion}

The issue of performance is very important in the organizational analysis process (Desreumaux, 2005). Youth leaders know well that taking into account social and environmental aspects, in addition to economic aspects, is necessary to ensure a sustainable development for the company and promote innovation, a significant source of competitive advantage. Indeed, employees would feel more comfortable and would be loyal and motivated when they believe they are useful and appreciated. Similarly, the leader would be more motivated and would work with enthusiasm. "Doing good makes you feel good". Enjoying an ethical and responsible attitude doesn't prevent the economic goals achievement. Moreover, when we show that being involved in socially responsible activities improves economic performance, we contribute to the promotion and the social acceptance of these activities (Gond, 2006).

We noticed that $16 \%$ of the Lebanese SMEs and $18.2 \%$ of the Romanian SMEs engage in CSR voluntarily. According to Waddock and Graves (1997), based on the assumption of available funds, the lowest-risk companies, i.e. companies enjoying a stable model, engage more than others in socially responsible activities. They have free resources, that are available for socially responsible activities and practices and that can improve their societal performance.

According to Schiopoiu Burlea and Domnisoru (2005), the company that uses a flexible system of social responsibility CSR, not only has a better chance to achieve its goals, but also to control the fluctuating competitive environment in which it operates.

Moreover, according to Saulquin and Schier (2007), companies define CSR according to their openness level (open or closed managerial view) and their managerial approach regarding performance (a static approach aiming at an economic performance or a dynamic approach including additional indicators). Four cases are possible and they could result in four types of performance views: procedural view, fragmented view, opportunistic view, and global view. It was noted in the present study that the performance view is fragmented. In this case, the CSR is confounded with performance, which means a static approach of performance and a closed view of the company. Indeed, $76 \%$ of the Lebanese SMEs and 63.6\% of the Romanian SMEs are willing to integrate the CSR into their activities in favor of performance.

In this case CSR is included in a business-oriented view, a utilitarian view that sees CSR as a tool, a tool to improve the performance of the company (Pasquero, 2005). Taking into consideration the expectations of the stakeholders is part of an instrumental perspective that seeks to perceive the economic and financial consequences relevant to the management of the stakeholders (Donaldson and Preston, 1995).

\section{Conclusion}

In this article, we were able to show that both the Lebanese and the Romanian SMEs consider financial performance the most important, even those which engage in socially responsible practices, as engaging in CSR will result in improving the company's performance.

Similarly, the importance of certain socially responsible practices to improve social performance of these companies and contribute thereafter to laying the foundation for a comprehensive performance approach in the Lebanese and Romanian SMEs was highlighted.The work limitations due to sample size are worth mentioning. It was very difficult to convince and motivate leaders to participate in this study. A larger number of SMEs would have improved the external validity of these findings. Similarly, it was very difficult to have access to the financial data of these companies.

Finally, based on the intended purpose and findings, trying to join actions designed to perform in the areas of ESG to their qualitative andlor quantitative, direct or indirect, potential effects on financial performance may lead to a new research path

Enriching the concept of ESG performance across the Lebanese and the Romanian SMEs could raise greater awareness of CSR issues. Specifically, we may advise through the ESG performance new methods of production and growth for the SMEs and we can detect practices that promote customer confidence in companies leading to a strong relationship. We also would like to identify management 
practices related to the Lebanese and the Romanian SMEs for multi-stakeholder governance method. All these elements aim at enhancing better risk management for a sustainable growth of the relevant SMEs. Therefore, we have to define multiple risks (financial, social, societal, environmental....) SMEs face and identify the necessary and adequate means to manage them.

\section{References}

[1] ALLOUCHE, J., LAROCHE, P. (2005), « Responsabilité sociale et performance financière des entreprises : une synthèse de la littérature », colloque : La responsabilité sociale de l'entreprise : réalité, mythe ou mystification?, Nancy, 17-18 mars 2005

[2] BADREDDINE, A. (2011), «Les effets de la multibancarisation sur le financement des PME par les banques », Thèse de doctorat en Sciences de Gestion, sous la direction de Fabrice ROTH, Ecole doctorale Sciences économique et de gestion, Université Lyon 3.

[3] BERGERON, H. MARCHAND, M., ROY, C. (2014), «Pilotage de la performance durable et PME : vers un tableau de bord intégratif », In. Labelle F., Hervieux C. et Turcotte M-F., LesPME en marche vers le développement durable, Presses de l'Université de Québec, Canada.

[4] BNOUNI, I. (2011), « Performance financière et performance sociale : Etat de l'art », Communication lors de la 20ème conférence de l'AIMS, Nantes, 7-9 juin.

[5] BOURGUIGNON, A. (2007), «Sous les pavés la plage...ou les multiples fonctions du vocabulaire comptable : l'exemple de la performance », Comptabilité Contrôle Audit, 1(3), 1997, 89-101.

[6] CAPRON, M., QUAIREL-LANOIZELÉE, F., (2010), La responsabilité sociale d'entreprise, 2 ème édition, La Découverte, Paris.

[7] CAPRON, M., QUAIREL-LANOIZELÉE, F., (2006), « Evaluer les stratégies de développement durable des entreprises : L'utopie mobilisatrice de la performance globale », Revue de l'organisation responsable, $\mathrm{N}^{0}$ 1, 5-17.

[8] CARROLL, A. (1979), “A three-dimensional conceptual model of corporate performance”, Academy of Management Review, 4(4), 500.

[9] CAZAL, D. (2011), «RSE et théorie des parties prenantes : les impasses du contrat », Revue de la régulation, $\mathrm{N}^{\circ} 9$.

[10] CCI (2014), «L'économie libanaise et arabe », Chambre de Commerce et d'Industrie, Beyrouth-Mont Liban, N ${ }^{\circ} 577$.

[11] CHIDIAC EL HAJJ, M. (2015), «Socially responsible community involvement in light of reports of Alpha commercial banks in Lebanon », http://www.escem.fr/docs/2015-05-22_actes_colloque.pdf

[12] CJD Centre des Jeunes Dirigeants d'entreprise (2012), La performance globale des entreprises responsables, Pour une économie au service de l'Homme et de la vie, $2^{\text {ème }}$ édition, France.

[13] COURRENT, J.M. (2012), RSE et développement durable en PME, Comprendre pour agir, De Boeck, Bruxelles.

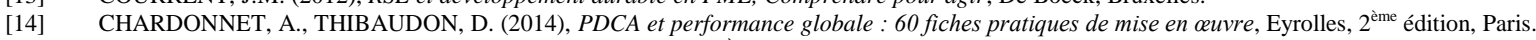

[15] DESREUMAUX, A. (2005), Théorie des organisations, EMS, $2^{\text {ème }}$ édition.

[16] DOHOU, A., BERLAND, N. (2007), « Mesure de la performance globale des entreprises », Comptabilité et Environnement, France.

[17] DONALDSON, T., PRESTON, L.E. (1995), « The stakeholder theory of the corporation: concepts, evidence and implications », Academy of Management Review, 20(1), 65-91.

[18] FREEMAN, E., McVEA, J. (2001), « A stakeholder approach to strategic management », In Hitt M. Freeman R.E. et Harrison J. Handbook of strategic Management, Oxford: Blackwell, 189-207.

[19] FREEMAN E. (1984), Strategic Management: a stakeholder Approach, Pitman, Boston.

[20] GERMAIN, C., TREBUCQ, S. (2004), «La performance globale de l'entreprise et son pilotage: quelques réflexions », Semaine sociale Lamy, No.1186, http://trebucq.u-bordeaux4.fr/1186-germain-trebucq.pdf (Page consultée le 18 septembre 2014)

[21] GOND, J.P. (2006), «Construire la relation (positive) entre performance sociétale et financière sur le marché de l'ISR : de la performance à l'autoréalisation ", Revue d'économie financière, $\mathrm{n}^{\circ} 85$.

[22] GRANDIN, P., SAIDANE P. (2011), La finance durable, une nouvelle finance pour le XXI siècle ?, Revue Banque, Paris.

[23] HIRIGOYEN, G., POULAIN-REHM, T. (2014), «Les relations de causalité entre responsabilité sociétale des entreprises et performance financière : approche internationale », Gestion 2000, 14 (2), 153-177.

[24] JENSEN, M.C. (2002), « Value Maximization Stakeholder Theory and the Corporate Objective Function », Business Ethics Quaterly, 12(2), $235-256$.

[25] JULIEN, P.A. (1990), "Vers une typologie multicritère des PME, Revue internationale P.M.E. : économie et gestion de la petite et moyenne entreprise », 3, (3-4), 411-425.

[26] LORINO, P. (2003), Méthodes et pratiques de la performance, Editions d'Organisation, 3 ème édition, Paris.

[27] LUTHI, T., MAILLY L. (2015), Améliorer la performance de votre entreprise : 70 recommandations concrètes pour 2015, Eyrolles, Paris.

[28] MAHÉ De BOISLANDELLE, H. (1996), "L'effet de grossissement chez les dirigeants de PME : ses incidences sur le plan du management des hommes et de la GRH », Congrès International Francophone sur la PME, Trois-Rivières, Canada.

[29] MARCHESNAY, M. (1991), « La PME: Une gestion spécifique », In : Economie rurale, Nouvelles approches en gestion de l'entreprise agricole. Session des 29 et 30 Novembre 1990 organisée par Jean-Marie Attonaty (INRA-ESR), Jacques Clément (DGER) et Louis-Georges Soler (INRASAD), 206 (206), 11-17.

[30] MAUREL, C., TENSAOUT M. (2014), «Proposition d'un modèle de représentation et de mesure de la performance globale », Comptabilité Contrôle - Audit, 3(20), 73-99.

[31] MEKDESSI, S. (2007), «Créer une performance socio-économique globale et durable, pour une qualité intégrale de l'entreprise ». Journal of Sciences de Gestion, Nb.60, Edition ISEOR, 2007

[32] ORLITZKY, M., SCHMIDT, F., RYNES S. (2003), «Corporate Social and Financial Performance: A Meta-analysis », Organization studies, 24(3), 403-441.

[33] PASQUERO, J. (2005), «La responsabilité sociale de l'entreprise comme objet des sciences de gestion: un regard historique ». In Turcotte M.F. et Salmon A., Responsabilité sociale et environnementale de l'entreprise, Presses de l'Université du Québec.

[34] PLATON, V., ANTONESCU, D., (2009), "The regional dimension of the SME sector in Romania", Journal of Urban and Regional Analysis, vol I, 1,2009 p. 17-26

[35] PRESTON, L., O’Bannon D. (1997), “The corporate social-financial performance relationship”, Business and Society, 36(4), 419-429.

[36] ROUSSEAU, P. (2012), «La performance sociétale est-elle mesurable? Le rôle des agences de notation extra-financière », in Igalens J., Laresponsabilité sociale des entreprises, Défis, risques et nouvelles pratiques, Eyrolles, Paris, pp. 100

[37] SAULQUIN, J.Y., SCHIER, G. (2007), « Des perceptions managériales aux pratiques RSE: une étude exploratoire », Gestion 2000, 24(6), 181-195.

[38] SAVALL, H., ZARDET, V. (2010), Maîtriser les coûts et les performances cachés, Prix de Management stratégique, Harvard-L'Expansion, Economica, $5^{\text {ème }}$ édition, Paris.

[39] SAVALL, H., ZARDET, V., BONNET, M. (2009), Management Socio-Économique, Une approche innovante, Economica, Paris.

[40] SAVALL, H., ZARDET, V. (2005), «Processus participatif de changement pour une performance socio-économique durable: Cas évalués d'entreprises et d'organisations », Gestion 2000, 22(5), 199-227.

[41] SBEIH, N. (2009), L'économie libanaise de A à Z, Dictionnaire économique, Le Commerce du Levant, Mars 2009.

[42] SCHIOPOIU BURLEA, A. (2015), «L'entrepreneuriat social : un défi et un pilier de la protection sociale » Croissance, population et protection sociale; faits et théories face aux enjeux, Editions Panthéon Assas, 229-241

[43] SCHIOPOIU BURLEA, A., DOMNISORU, S. (2005), «L'Audit social de la RSE un nouveau défi pour les entreprises roumaines », Performances économiques \& performances sociales à l'heure de la RSE, 605-612

[44] SDC (2015), The Swiss Agency for Development and Cooperation, SMEs as engine of growth and development, https://www.eda.admin.ch/dam/erweiterungsbeitrag/fr/documents/Projekte/KMU-Rumaenien-FR.pdf

[45] TORRES, O. (2003), « Petitesse des entreprises et grossissement des effets de proximité », Revue Française de Gestion, 3 (144), 119-138.

[46] VANCE, S.C. (1975), “Are Socially Responsible Corporations Good Investment Risks?” Management Review, 64(8), 18-24.

[47] WADDOCK, S., GRAVES, S.B. (1997), “The Corporate Social Performance-Financial Performance link”, Strategic Management Journal, 18(4), 303319.

[48] ZELLER, T.L., STANKO, B., CLEVERLEY, W. (1996), «A revised classification pattern of hospital financial ratios », Journal of Accounting and Public Policy, 15, 182-191. 